\title{
From the Desk of the Honorary Secretary General
}

At the outset, I have pleasure to inform you that following an invitation from International Institute of Welding a five member delegation from IIW-India comprises of M/s. R. Srinivasan, President, Parimal Biswas, Hony. Secretary General, Alak Kumar Mitra, Director, ANBCC-India, Bimal Kumar Das, Chairman, ANB-India and A. K. Bhaduri, Past Vice President, IIW-India participated in the 68th Annual Assembly \& International Conference of International Institute of Welding (IIW) at Helsinki, Finland during 28th June to 3rd July, 2015. Our team members attended various commission meetings and IAB meetings.

Regarding IIW-India activities, it may please be noted that in line with the decisions taken by Central Council, all Branches have completed their Annual General Meeting for the year 2014-15 within time. Thanks to all of them. Moreover, I am also pleased to inform you that our Branches have also been organizing activities at a regular interval, the highlights of which are given below

- Hyderabad Branch organized one day workshop on "Advances in Materials Joining Technology, on 29th May at Hyderabad,

- Baroda Branch had organized IWB/IWT certification course, Industrial visit including Five days Refresher course on Pressure Vessels,

- Bhilai Branch organized Training workshop at site, Foundation Day Celebration and Technical Symposium,

- Cochin Branch organized a seminar on "Welding Technology in the country" at AISAT, Cochin,

- Chennai Branch organized three days course on Welding Technology, Metallurgy and Quality Assurance (WTMQ-2015),

- Delhi Branch planned to organize Branch Seminar during August, 2015.

Skill Development Activity, which is one of the prime activities of IIW-India nowadays, has been progressing satisfactorily. Our Institute is collaborating with various Sector Skill Councils (SSCs) both as a Knowledge Partner and as an Assessing Agency.

You are aware that Golden Jubilee Celebration of the Institute will be beginning with 6th IIW Welding Research \& Collaboration Colloquium, the first time to be held at Hyderabad during 22-24 April, 2016 and will be concluded with the National Welding Seminar-2016 along with WELD INDIA EXHIBITION at Kolkata during 15-17 December 2016. Prior to this celebration Mumbai Branch will be organizing NWS-2015 during 9-11th December, 2015 along with 10th Welding Technology Exhibition at Navi Mumbai during 10-12th December, 2015. I would request all members to extend their co-operation to make these events successful.

Further, it has been proposed that next Annual General Assembly including 49th Annual General Meeting of IIW-India will held during 25th and 26th September, 2015 at the Hotel Golden Parkk, Kolkata. On this occasion IIW-India's various divisions meetings will also be held. I would request all the Council Members and Branch Office Bearers to attend these meetings.

With warm regards

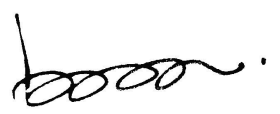

\section{Parimal Biswas}

M.No +91 9831052652

E-Mail Id : parimal.biswas@iiwindia.com 